\title{
The University Archaeological Collections from their Inception until Today. The University of Graz as a Case Study for teaching
}

\author{
By Maria Christidis*
}

Archaeological collections are closely linked to institutes of Archaeology at Universities, and have a long tradition. Since the 18th century, but especially since the beginning of the 19th century archaeological artefacts as well as casts have been consciously acquired for teaching. Thus, numerous highly valued archaeological collections were formed. The Second World War was followed by a decline, which is now superseded by a significant upturn. Over time a lot has happened and changed. The rapid development of technology in the recent decades has left its effects also in the field of archaeology and has contributed to its modernisation. In this paper the role of the University of Archaeological Collections, in teaching, research and public, will be presented. This will be demonstrated with the case study of Graz. Further it will focus on the function and activity of such collections such as a didactical tool today.

Most University Departments of Archaeology in Europe are connected to related collections. The Archaeological Collections of Graz include two parts: the original artefacts and the plaster casts. The "archaeological cabinet" of the originals, reproductions and photographs was constituted in 1865 in order to support the teaching of the classical studies ${ }^{1}$.

Figure 1. Archaeological Collections, University of Graz

Source: J. Kraschitzer 2015

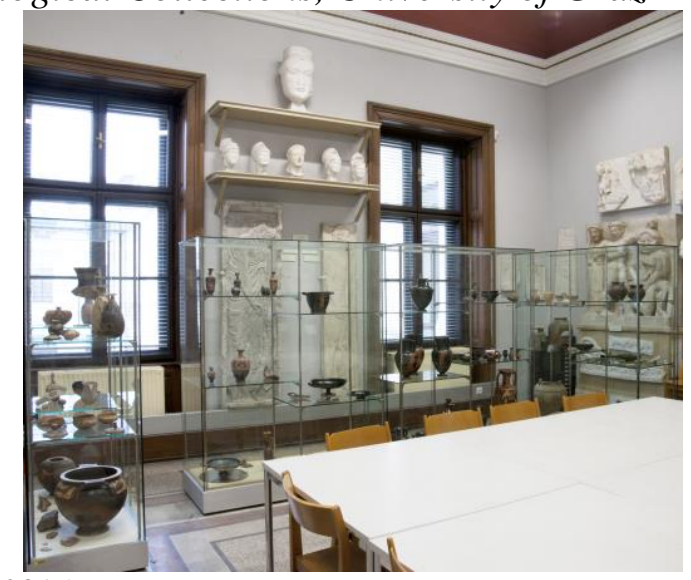

\footnotetext{
* Scientific Assistant, University of Graz, Austria.

1. Erwin Pochmarski, Die Geschichte der archäologischen Sammlungen der Universität Graz [The history of the archaeological collections of the University of Graz], 2008, accessed July, 3, 2015, http://bit.ly/1OXsJRc.
} 


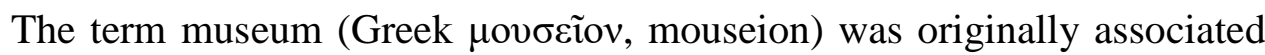
with the sanctuary of the Muses, the protective goddesses of arts, culture and science. A museum was part of a philosophical institution and a place where the teaching material was stored ${ }^{2}$. During the Renaissance the terms "museum, studio, studioso, galleria, cabineto or raccolta" were equally used for collections of paintings, books and other works of art. Since the foundation of National Museums though, only the term museum has been established.

In the following we will look at these tasks using the University Collection of Graz as an example. According to the ICOM-definition "a museum is in charge of accomplishing four tasks: acquire, conserve, research and exhibit" ${ }^{3}$.

\section{Acquire}

The collection of the Archaeological Institute of Graz holds more than 2000 original artefacts, containing pottery, whole vessels or fragments, as well as objects made of bronze, glass and other materials. The cast collection contains over 400 sculptures from the Greek Archaic to the Roman period ${ }^{4}$. An interest towards the classical period of art can be noticed here just like in other cast collections ${ }^{5}$. Plaster casts were already known in antiquity ${ }^{6}$ when they

2. About a review of the term and the history of a museum, see François Mairesse, "The Term Museum," in What is a Museum?, ed. Ann Davis et al. (München: Verlag Dr. C. MüllerStraten, 2007), 19-25; Wolf D. Heilmeyer, "Mouseion - Museum: Kleiner Überblick zum Namen und zur Geschichte der Museen" ["Museum: Brief Introduction to the name and the history of museums"], in Erst erfreuen, dann belehren. Museologie und Archäologie, ed. Wolf D. Heilmeyer, (Berlin: G+H-Verlag 2013), 22-24. Diog. Laertius 5.51; Paus. 1.30.2, Andreas Glock "Museion", Der neue Pauly. Enzyklopädie der Antike VIII (2000), 507-511; The "Mouseion" of Alexandria, founded in the early Hellenistic period, was one of the most important research institutions of the ancient world (Strabo 17.1.8; Suet. Claud. 42). It was equipped with roofed and open plan function rooms (exedra and peripatos) with a restaurant (oikos), presumably with official residences and gardens too, but also with the famous library. Collecting significant objects, however, was associated with shrines. In Treasuries, the thesauroi, precious objects were stored. There were objects that were permanently placed in the shrines and temples or others that were shown in special cases during certain festivals (special exhibition). In the Pinacotheca - at the left wing of the Propylaea at the Acropolis of Athens - were kept pictures of renowned painters (Paus. 1.22.6-7).

3. "ICOM: The world museum community," Icom Corporation, accessed May 2015, http://bit.ly/1Bk9R5o; Hildegard K. Vieregg, Museumswissenschaften: eine Einführung [Museum Sciences: an introduction] (Stuttgart: UTB Verlag, 2006), 15-23.

4. Markus U. Heinrich, "Zur Herstellung von Gipsabgüssen," ["For the production of plaster casts"], in Gips nicht mehr. Abgüsse als letzte Zeugen antiker Kunst, ed. Johannes Bauer and Wilfrid Geominy (Bonn: Köllen Druck und Verlag, 2000): 47f.

5. The casts were intended to support the aesthetic and artistic education, on account of this plaster cast were produced mainly in the tradition of classicism, which considered as exemplary, see Johannes Bauer, "Gipsabgußsammlungen an deutschsprachigen Universitäten" ["Plaster Cast Collections at German Universities"], Jahrbuch für Universitätsgeschichte 5 (2002): 121, not. 15 .

6. Terms: Abguss-Sammlung or Gipsmuseum (ger.), cast collection (engl.), mouseio ekmageion (gr.), musée des moulages (fr.), gipsotheca (it.). Ancient terms of the plasters were: apomagma, sphragis, apomaxasthai, later following terms were also applied: gypsoplastes, gypsoplasia. The use of plasters is recorded both by the ancient sources (Theophr. On Stones 
were used for the production of marble or bronze sculptures, as copies or as artworks themselves ${ }^{7}$.

Figure 2. Cast Collection, University of Graz

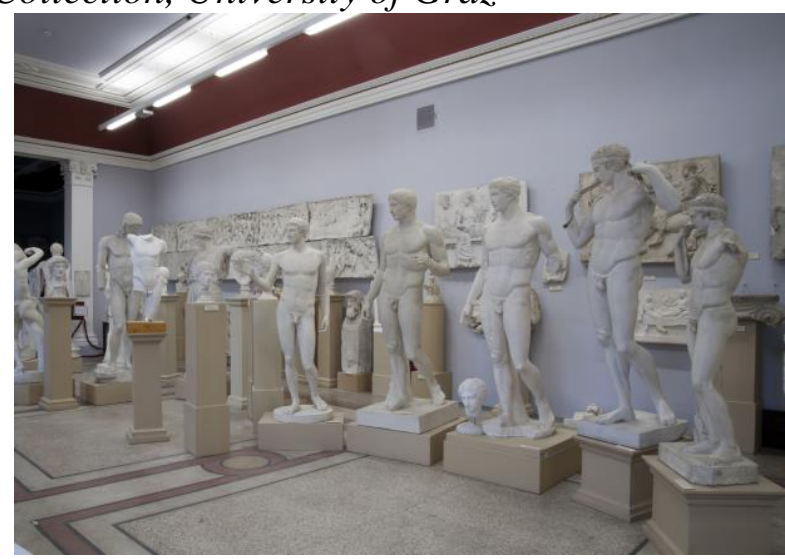

Source: J. Kraschitzer, 2015

The history of the collections is linked to the general interest in the ancient world. In the Renaissance we see a first approximation, commitment and admiration of antiquity ${ }^{8}$. In the 18 th century some collections (e. g. Dresden Art Academy) were declared as academies and were open to the public from the 19th century on. In the following years intensive excavations in the Mediterranean Sea were carried out. The transport of antiques from the archaeological sites abroad though was prohibited by law ${ }^{9}$. As a result an

64-69) as well as by archaeological findings. Funerary masks, wigs, reliefs, statues, and even portraits have been preserved in plaster; Ingeborg Kader, "Abguß/Abgußsammlung", Der neue Pauly. Enzyklopädie der Antike XIII, (1996): 1-6; Rune Frederiksen, "Plaster Casts in Antiquity", in Plaster Casts. Making, Collecting and Displaying from Classical Antiquity to the Present, ed. Rune Frederiksen and Eckart Marchand (Berlin: De Gruyter, 2010), 13-15.

7. The oldest examples of plaster casts are originated in Egypt, in the workshop of the Sculptor Thutmose at Amarna, and are dating back to the end of the eighteenth Dynasty, between 1351-1334 B.C.E., see: Rune Frederiksen, "Plaster Casts in Antiquity", in Plaster Casts. Making, Collecting and Displaying from Classical Antiquity to the Present, ed. Rune Frederiksen and Eckart Marchand (Berlin: De Gruyter, 2010), 15-17. At the gulf of Naples, in Baiae more than 400 fragments of plaster casts of statues were found placed in a basement in the area of the Sosandra thermal baths, see Christa Landwehr, Die antiken Gipsabgüsse aus Baiae [The ancient plaster casts of Baiae] (Berlin: Mann Verlag, 1985).

8. Claudia Danguillier, "Abgußsammlungen" ["Molding Collections "], in Gips nicht mehr. Abgüsse als letzte Zeugen antiker Kunst, ed. Johannes Bauer and Wilfried Geominy (Bonn: Köllen Druck und Verlag, 2000), 34.

9. Johannes Bauer, "Gipsabgußsammlungen an deutschsprachigen Universitäten" ["Plaster Cast Collections at German Universities"], Jahrbuch für Universitätsgeschichte 5 (2002): 124-126. Replica workshops in Europe: Paris, Louvre: the replica workshop in Louvre - atelier de moulage - was established in 1794, cf. "Atelier de moulage du Musée du Louvre", Musée du Louvre Corporation, accessed July 3, 2015, http://bit.ly/1KZdpiS; Berlin, Charlottenburg: the replica workshop, which was founded in 1819 by King Friedrich Wilhelm III as the "royal Prussian plaster casting institution", has become the "world's largest institution of its kind": Gipsformerei, Stiftung Preußischer Kulturbesitz Corporation, accessed July 3, 2015, http://bit.ly/1QVS8Iy; Pella: Ergasterio Ekmageion, Ephoria Archaiothton Pellas Corporation, accessed July 3, 2015, http://bit.ly/1hnspMT. Another method quite new, is the 
intensive production of plaster copies arose and the need of them as teaching materials at universities increased. At the last quarter of the 19th century the casting collections have had their heyday along with the establishment or extension of collections at universities ${ }^{10}$. At the beginning of the 20th century and into the 1970s the cast collections were not highly appreciated in contrast to the original artefacts. But since the 1980s the cast collections receive an upturn, which will hopefully remain ${ }^{11}$.

\section{Conserve}

The term "conserve" is related to security, restoration and conservation of the museum's objects. At the University of Graz the original artefacts as well as the plaster casts undergo such procedures ${ }^{12}$.

\section{Research}

The University Collections in Graz are closely linked to research ${ }^{13}$. The figured Greek and Italian vases were scientifically examined and published in a

reproduction by 3D printer, see 3D-Druck für Museen und Ausstellungen, accessed May 27, 2015, http://bit.ly/1McdQUP. This method is not so effective, since details of the surface are not recorded, cf. S. Karl - E. Trinkl, Studie zur Relevanz archäologischer Reproduktionen für Universitäten, Museen, Denkmalschutz und Forschungsvorhaben [Study on the Relevance of archaeological reproductions of universities, museums, conservation and research projects], (unpublished final report, Graz 2014).

10. There are also University collections with a different focus, thus the Uniseum, the University museum of the Albert-Ludwigs-University in Freiburg presents the development of the University since its founding (Uniseum Freiburg, Universität Freiburg Corporation, accessed July 3, 2015, http://bit.ly/1GtTyUQ).

11. Claudia Danguillier, "Abgußsammlungen" ["Molding Collections "], in Gips nicht mehr. Abgüsse als letzte Zeugen antiker Kunst, ed. Johannes Bauer and Wilfried Geominy (Bonn: Köllen Druck und Verlag, 2000), 37-40; Johannes Bauer: "Gipsabgußsammlungen an deutschsprachigen Universitäten" ["Plaster Cast Collections at German Universities "], Jahrbuch für Universitätsgeschichte 5, (2002): 127-130. The same phenomenon occurred also in USA, since the 80ies the cast collections revived, William J. Battle Collection of Plaster Casts, University of Texas at Austin, see Stephen L. Dyson, Cast Collecting in the United States, 573-57. The didactic - chronological, thematic or typological - criteria of an exhibition design, were still underdeveloped. The objects should be the focus and be admired, see Katharina M. Mrak, Vermittlung im Museum. Museumspädagogische Konzepte steirischer Museen für Kinder [Mediation in the museum. Educational Concepts of Styrian museums for children ] (Master Thesis, University of Graz, 2014), 21.

12. Preservation is a major function of museums in order to communicate what each museum has retained as evidence worthy of interest, see Andrée Desvallées, "Definition of Museum" in What is a Museum? ed. Ann Davis et al., (München: Verlag Dr. C. Müller-Straten, 2007), 127. The restaurateurs R. Fürhacker - A.K. Klatz were in charge to restore several vessels in course of the publication of M. Christidis et al., "Originalsammlung des Instituts für Archäologie der Karl-Franzens-Universität Graz 1" ["Original Collection of the Institute of Archaeology of the Karl-Franzens-University of Graz 1"] in Corpus Vasorum Antiquorum, Österreich, (Vienna: Verlag der Österreichischen Akademie der Wissenschaften, 2000). 
recent volume of the Corpus Vasorum Antiquorum (CVA) series ${ }^{14}$. The documentation of the objects is connected mainly to "research" but it refers also to other functions of a museum. In case of the Graz collections, the original artefacts have been entirely digitally inventoried and the inventory of the cast collection is in progress. The objects are presented at an online portal of the University of Graz along with other University collections ${ }^{15}$. Further the plaster casts are subject to research to certain aspects like artist's assignments, techniques or production, i. e. the researches in order to identify the authenticity of the Satyr Group, a plaster of which is situated in Graz ${ }^{16}$.

\section{Exhibit}

Collections provide the foundation for museums or exhibitions, but they are not themselves a museum. The museums are obliged to not only collect and investigate the works of art, but also to present them to the public ${ }^{17}$. In this regard the objects set up the basis for each activity of the museum ${ }^{18}$. Through exhibition museums disseminate their own research or that of others to the public $^{19}$. The Archaeological Collections of the University of Graz were

13. It is a place of universities and museums to conduct research and it is the place of museums as public institutions to disseminate that research and make the results understandable to the public through publications, exhibitions and public programming, see Irene Bald-Romano, "Scholarship in Anthropology, Archaeology, and Ethnography Museums", in Scholarship and museums. Roles and responsibilities, ed. Bryant F. Tolles, Jr. (Newark 1988), 63.

14. The original collection of Graz possesses pottery (whole vessels or fragments) from all kinds of classes, concerning chronological and geographical criteria. It is significant the difference between a University and a private collection. A private collector acquires objects after his personal taste. The primary purpose of a University is the teaching and the original collection is incumbent of this function.

15Maria Christidis et al., "Die archäologischen Sammlungen der Universität Graz auf dem Weg ins digitale Zeitalter" ["The archaeological collections of the University of Graz on the way to the digital age"]. Forum Archaeologiae 75, VI (2015), accessed 7 July 2015, http://farch.net.

16. Hans-Thuri Lorenz, "Satyroi. Anmerkungen zu einem Brief aus dem Jahre 14883" ["Satyrus. Comments on a letter from the year 14883 "], in Orham Bingöl's 67. Yas Armagani ed. Görgem Kökdemir (Ankara: Bilgin Kultur Sanat), 379-387.

17Ivo Maroevic, Introduction to museology. The European approach (Munich: Verlag Dr. Christian Müller-Straten 1998), 267.

18. As soon as an object is removed from its enviroment and intergrated in a museum, it becomes potentially an exhibit; Andrée Desvallées, "Definition of Museum", in What is a Museum? ed. Ann Davis et al., (München: Verlag Dr. C. Müller-Straten 2007), 127. Astrid Petrson, Wissensvermittlung in Museen. Eine Analyse von Museums- und Ausstellungskonzepten unter Berücksichtigung pädagogischer Lerntheorien am Beispiel des Universalmuseums Joanneum [Knowledge in museums. An analysis of museum and exhibition concepts, taking into account pedagogical theories of learning, using the example of the Universalmuseum Joanneum], (Ph. D., University of Graz, 2011), 24-25.

19. See Evelyn E. Douglas, "Scholarship in the History Museum: New frontiers of doing the job better?" in Scholarship and museums. Roles and responsibilities, ed. Bryant F. Tolles, Jr. (Newark 1988), 47. Ivo Maroevic, Introduction to museology. The European approach 
accessible to the public from the beginning. In recent years additional public activities take place, like the participation in the Children's University ${ }^{20}$ or in the Night of Museums ${ }^{21}$.

\section{The Archaeological Collections in Graz Today}

When we think about museums, we think about great buildings with quiet, tidy rooms and spotless floors, where the objects are the only things in place. This is the popular view of a museum. Regarding our museum at the University of Graz we are confronted with a different situation: there are also desks, chairs, computers, people who work, make research, write papers etc.

Therefore the rooms of the archaeological collections are a place where students or staff and the objects build a symbiosis. This is not a "museum" where everything remains quiet and untouched but it is a working area, a place for academic discourse, were knowledge can be gained every day ${ }^{22}$. Lectures with material from the original and the cast collection take place on a regular basis. In addition, lectures of other faculties like the University of fine arts, or drawing lessons are included in the daily program.

\section{The Museum as Education Place in General}

A museum was originally a synonym for a place where collections were stored, exhibited and presented. But nowadays a "museum" is also considered to be an educational place ${ }^{23}$. In the ICOM definition of museums the term "education" is mentioned more than one time implicit or explicit, which points

(Munich: Verlag Dr. Christian Müller-Straten, 1998), 277-285. Communication of the featrures and values of cultural heritage

20. "Kinderuni" ["Children's University"] Karl-Franzens-Universität Graz Corporation, accessed June 12, 2015, http://bit.ly/1jaBBpF; Katharina M. Mrak, Vermittlung im Museum. Museumspädagogische Konzepte steirischer Museen für Kinder [Mediation in the museum. Educational Concepts of Styrian museums for children] (Master Thesis, University of Graz, 2014), 17

21. "Lange Nacht der Museen" ["Long Night of Museums"] ORF Marketing \& Creation GmbH \& Co KG Corporation, accessed June 12, 2015, http://langenacht.orf.at.

22. About the definition of Museum Archaeology, see Hedley Swain, An Introduction to Museum Archaeology (New York: Cambringe University Press, 2007) 11-13.

23. Christine Bäumler, "Bildung und Unterhaltung," in Das magische Dreieck, ed. Heike Kirchhoff et al., (Bielefeld: transcript-Verlag GmbH, 2007), 41-56; Heese Thorsten, "Außerschulische Lernorte im Geschichtsunterricht: Das Museum" ["Extracurricular places of learning in the teaching of history: The Museum"], in Geschichte erfahren im Museum, ed. Bärbel Kuhn et al., (St. Ingbert: Rohrig Universtitätsverlag, 2014), 14f.; Diethard Herles, Das Museum und die Dinge. Wissenschaft-Präsentation-Pädagogik [The museum and the things. Science-presentation-pedagogy], (Frankfurt: Campus Verlag GmbH, 1996), 33-38; Katharina M. Mrak, Vermittlung im Museum. Museumspädagogische Konzepte steirischer Museen für Kinder [Mediation in the museum. Educational Concepts of Styrian museums for children ] (Master Thesis, University of Graz, 2014) 13. 
out its importance. The word "education" refers not only to academics but to everybody.

Thus learning constitutes a major part of the museum's service to the public $^{24}$. This was detected since the beginning of the 20th century through visitor studies, museum associations and new journals ${ }^{25}$. Out of this need a relatively new field of study, "Museum Education", developed as a discipline of its own right within pedagogy ${ }^{26}$. The term pedagogy comes from "pais agein" and deals with any actions of education ${ }^{27}$.

Since the beginning the "Museum Education" was marked by a variety of methods and approaches without having any general structure. Due to the increasing involvement of museums in school and preschool education and the stronger promotion of adult education, "Museum Education" has become an organized branch of pedagogy ${ }^{28}$. Weschenfelder and Zacharias claim that "Museum Education" is the general term for all didactic, methodological and media issues concerning communication and education feature at museums. "Museum Education" should be understood as a conscious and intentionally staged process, which takes place actively between the subject (observer) and object $^{29}$. It distinguishes itself from simple preparation and presentation of the museum's objects. In this sense, all relevant object-related information is to be conveyed. During the process of museumization the objects lost their initial

24. Learning resp. Teaching is a major function that a museum must fullfill and this was the case in its original form with the Mouseion of Alexandria, see Andrée Desvallées, "Definition of Museum", in What is a Museum? Ann Davis et al., (München: Verlag Dr. C. Müller-Straten 2007), 129.

25. Hildegard K. Vieregg, Museumswissenschaften: eine Einführung [Museum Sciences: an introduction] (Stuttgart: UTB Verlag, 2006), 101.

26. Klaus Weschenfelder and Wolfgang Zacharias. Handbuch Museusmspädagogik. Orientierungen und Methoden für die Praxis [Handbook Museum Education. Orientations and methods for practice] (Düsseldorf: Schwann Verlag KG, 1981), 21-30. The presentation of the objects should convey the knowledge and support the required by the pedagogy "learning process", see Astrid Petrson, Wissensvermittlung in Museen. Eine Analyse von Museums- und Ausstellungskonzepten unter Berücksichtigung pädagogischer Lerntheorien am Beispiel des Universalmuseums Joanneum [Knowledge in museums. An analysis of museum and exhibition concepts, taking into account pedagogical theories of learning, using the example of the Universalmuseum Joanneum] (Ph. D., University of Graz, 2011), 43; Katharina M. Mrak, Vermittlung im Museum. Museumspädagogische Konzepte steirischer Museen für Kinder [Mediation in the museum. Educational Concepts of Styrian museums for children] (Master Thesis, University of Graz, 2014), 13-49.

27. An educational theory requires a theory of knowledge (epistimonology), a theory of learning and a theory of teaching, see George E. Hein, Learning in the Museum (New York: Routledge 1998), 16-40.

28. Klaus Weschenfelder and Wolfgang Zacharias, Handbuch Museusmspädagogik. Orientierungen und Methoden für die Praxis [Handbook Museum Education. Orientations and methods for practice] (Düsseldorf: Schwann Verlag KG, 1981), 13-20; Astrid Petrson, "Wissensvermittlung in Museen. Eine Analyse von Museums- und Ausstellungskonzepten unter Berücksichtigung pädagogischer Lerntheorien am Beispiel des Universalmuseums Joanneum" (Ph. D., University of Graz, 2011), 58.

29. Klaus Weschenfelder and Wolfgang Zacharias. Handbuch Museusmspädagogik. Orientierungen und Methoden für die Praxis [Handbook Museum Education. Orientations and methods for practice] (Düsseldorf: Schwann Verlag KG, 1981), 32. 
contexts and were separated from their social and historical environment. Therefore it is necessary to reconstruct these backgrounds as far as possible and to reveal them to the visitor ${ }^{30}$.

Teaching is a part of pedagogy that deals with forms of scheduled learning in several educational situations. Teaching is called a situation, in which learning is initiated, encouraged and facilitated within a specific institutional framework, with pedagogical intention by professional teachers. Teaching is thus focused on the transfer of new information giving importance to the acquisition of knowledge and skills as well as their application ${ }^{31}$. However, museum didactic differs from museum education ${ }^{32}$. Museum didactic is used to transfer certain contents and is responsible for their selection. Museum education intends to link this knowledge with contents of museum objects and aims for a personality-promoting effect as well ${ }^{33}$.

The main goal of museum education is to present museums as a place of learning and providing clear and understandable messages. Museum education permits the visitors to enjoy the exhibitions, which teach them information and values at the same time ${ }^{34}$.

In the recent years it is common that museums are connected to school lessons. Teaching can be supplemented by visiting a museum, but there should be a distinction between learning in the museum and in the classroom ${ }^{35}$.

30. Diethard Herles, Das Museum und die Dinge. Wissenschaft-Präsentation-Pädagogik [The museum and the things. Science-presentation-pedagogy] (Frankfurt: Campus Verlag $\mathrm{GmbH}$, 1996), 39-45; Klaus Weschenfelder and Wolfgang Zacharias, Handbuch Museusmspädagogik. Orientierungen und Methoden für die Praxis [Handbook Museum Education. Orientations and methods for practice] (Düsseldorf: Schwann Verlag KG, 1981), 70; Graeme K. Talboys, Using museums as an educational resource. An introductory handbook for students and teachers (Brookfield: Arena, 1996), 112.

31. Astrid Petrson, Wissensvermittlung in Museen. Eine Analyse von Museums- und Ausstellungskonzepten unter Berücksichtigung pädagogischer Lerntheorien am Beispiel des Universalmuseums Joanneum [Knowledge in museums. An analysis of museum and exhibition concepts, taking into account pedagogical theories of learning, using the example of the Universalmuseum Joanneum] (Ph. D., University of Graz, 2011), 47, 169.

32. Bernd Rese, Didaktik im Museum. Systematisierung und Neubestimmung [Teaching at the museum. Systematization and redefinition] (Bonn: Dr. Rudolf Habelt GmbH, 1995), 31-38.

33. Diethard Herles, Das Museum und die Dinge. Wissenschaft-Präsentation-Pädagogik [The museum and the things. Science-presentation-pedagogy] (Frankfurt: Campus Verlag $\mathrm{GmbH}, 1996), 60.225$; Astrid Petrson, Wissensvermittlung in Museen. Eine Analyse von Museums- und Ausstellungskonzepten unter Berücksichtigung pädagogischer Lerntheorien am Beispiel des Universalmuseums Joanneum [Knowledge in museums. An analysis of museum and exhibition concepts, taking into account pedagogical theories of learning, using the example of the Universalmuseum Joanneum] (Ph. D., University of Graz, 2011), 60. According to Rese the museum education is much more than an extension of the school pedagogy see Bernd Rese, Didaktik im Museum. Systematisierung und Neubestimmung [Teaching at the museum. Systematization and redefinition] (Bonn: Dr. Rudolf Habelt GmbH, 1995), 41.

34. According to Bäumer the role of entertainment in the museum is additive and distinctive, cf. Christine Bäumler, "Bildung und Unterhaltung" ["Education and Entertainment"], in Das magische Dreieck, ed. Heike Kirchhoff et al., (Bielefeld: transcriptVerlag GmbH, 2007), 45f. Christine Bäumler, Bildung und Unterhaltung im Museum. Das museale Selbstbild im Wandel (Münster: LIT, 2014), 47-66.

35. Ministry of education, women, children, cf. Katharina M. Mrak, Vermittlung im Museum. Museumspädagogische Konzepte steirischer Museen für Kinder [Mediation in the 
However, imparting knowledge in a museum can be guided by the principles of learning theories and these can be used as a foundation for an adapted education theory to the needs of museums.

In the case of "University Collections", it is important to use both, the traditional teaching and didactic methods and the study field of the museum education $^{36}$. The first and most important goal should be the enhancement of the learning. This depends on the framework conditions of a lecture, for example, through examination, presentation etc. Further, the way of the presentation of the objects should be considered, in order to keep in mind as much information as possible $\mathrm{e}^{37}$. The objects of museums should be regarded as an important aid for teaching, a visual support that extends the theoretical part of a university lecture.

\section{Collections as Tool for Teaching}

With the archaeological collections as a part of the lectures, students have the opportunity to look at objects up close, in original size and dimensions and to study them undisturbed. Concerning ceramic fragments or other small finds of the original collection this means the students are able to take the artefacts in the hand, touch, feel, measure, draw them, classify them and make comparisons. Through this procedure the various materials can be examined and interpreted. Vividness results from visibility, from looking at something directly. For example, materiality, proportion, colour, shape and treatment are visible. The field of archaeology is based on observing, so both archaeology and museums create the ideal conditions for the learning process by looking ${ }^{38}$. In this case the approaches of "Museum Education" are important, because in museums it is mainly about watching and knowing. However the "Museum Education" aims to transport information of abstract objects clearly and haptically, so they can be understood by the visitor ${ }^{39}$.

museum. Educational Concepts of Styrian museums for children] (Master Thesis, University of Graz, 2014), 31.

36. Museums fit into an educational sector and need to define appropriate roles in relation to both classroom-based instruction and various forms of non-didactic and learner directed education through exhibitions or other activities based on the museums collections, see Evelyn E. Douglas, "Scholarship in the History Museum: New frontiers of doing the job better?" in Scholarship and museums. Roles and responsibilities, ed. Bryant F. Tolles, Jr. (Newark, 1988), 42.

37. Through visualization Information can be understood and memorized better and easier, Brigitta K. Pfäffli, Lehren an Hochschulen. Eine Hochsuldidaktik für den Aufbau von Wissen und Kompetenzen [Teaching at universities. Teaching for building competences] (Stuttgart: Haupt Verlag), 217-224. Some writers assort two types of education, the "formal", which takes place in the school and the "informal education" that is to be provided in a museum, George E. Hein, Learning in the Museum (New York: Routledge, 1998), 7.

38. Klaus Weschenfelder and Wolfgang Zacharias, Handbuch Museusmspädagogik. Orientierungen und Methoden für die Praxis [Handbook Museum Education. Orientations and methods for practice] (Düsseldorf: Schwann Verlag KG, 1981), 73.

39. Katharina M. Mrak, Vermittlung im Museum. Museumspädagogische Konzepte steirischer Museen für Kinder [Mediation in the museum. Educational Concepts of Styrian 
An essential function of the museum is the training of sensory perception. Museums are generally places which provide aesthetic perception and sensual experience $^{40}$. For the visitors it is more important to experience the museum objects directly and on site, than to receive information about them indirectly, based on foreign observations and testimonials ${ }^{41}$. Museums create experience at first hand ${ }^{42}$. Only in a cast collection one has the opportunity to see the sculptures three-dimensional, from all perspectives and this intensive study enables the training of visual learning and perception ${ }^{43}$.

In an era of image flood, the museum allows the objects to stand still and enables us to make them understandable by comparison ${ }^{44}$.

The objects of the archaeological collection are also objects of art and therefore their analysis requires learning aesthetic education. One can therefore consider the dimensions of the statues in the room in comparison to the human proportions accurately. The viewer can interact with the objects. The juxtaposition as well as the comparison of the artefacts of several categories, such as sculpture, architecture and ceramics contributes to achieve a nearly complete picture of ancient art. Additional information of the objects such as aspects of material, technology and manufacturing demonstrate social issues of the ancient cosmos and are relevant to other fields of study, such as history.

Working with pictorial material can be more difficult than working with documentary material. The main reason for the difficulty, however, lies in the fact that pictorial materials are more open for investigation than the written word as they contain more information in a less defined form. If we see the statues and not their pictures we come closer to their context.

Another parameter of didactic, also provided in the archaeological collections, is authenticity, originality, and uniqueness that cause an

museums for children] (Master Thesis, University of Graz, 2014), 14. 75: Essential learning does not take place in the abstract, in dealing with concepts, but in concrete terms in dealing with sensory perception and tangible objects in the surrounding reality.

40. Christine Bäumler, Bildung und Unterhaltung im Museum. Das museale Selbstbild im Wandel [Education and Entertainment at the Museum. Changing of Museum's self-image ](Münster: LIT, 2014), 17-20.

41. After A. Cornelius, the major exponent of educational realism, cf. Katharina M. Mrak, Vermittlung im Museum. Museumspädagogische Konzepte steirischer Museen für Kinder (Master Thesis, University of Graz, 2014), 21.

42. Christine Bäumler, Bildung und Unterhaltung im Museum. Das museale Selbstbild im Wandel [Education and Entertainment at the Museum. Changing of Museum's selfimage](Münster: LIT, 2014), 17-20. Ivo Maroevic, Introduction to museology. The European approach (Munich: Verlag Dr. Christian Müller-Straten, 1998), 306: Didactic exhibitions communicate knowledge using both museum material and museographic devices. It is possible to stage a didactic exhibition without using museum material, but in that case their authenticity decreases. The museum experiences must be in any case organised to be educative, George E. Hein, Learning in the Museum (New York: Routledge, 1998), $2 \mathrm{f}$.

43. Katharina M. Mrak, Vermittlung im Museum. Museumspädagogische Konzepte steirischer Museen für Kinder [Mediation in the museum. Educational Concepts of Styrian museums for children] (Master Thesis, University of Graz, 2014), 29.

44. Thorsten Heese, "Außerschulische Lernorte im Geschichtsunterricht: Das Museum" ["Extracurricular places of learning in the teaching of history: The Museum"], in Geschichte erfahren im Museum, ed. Bärbel Kuhn et al. (St. Ingbert: Rohrig Universtitätsverlag, 2014), 15. 
auratization of museum objects. Authenticity means that an object stores a testimony about itself and about the time and place remote conditions ${ }^{45}$. The role of the casts is double and ambivalent: They are replacements of the original objects but they are also individual objects or else original objects themselves. They represent museum objects as they have a certain age and are considered to be documents of a past epoch ${ }^{46}$. The authenticity is not missing in this case too.

For students it is important to leave the classroom for a while and to visit the museum for the forthcoming of their lecture. There is no doubt that in museums knowledge can be provided in a different way, i.e. they can learn actively, and according to educational theorists, active learning is more efficient than passive learning. In addition, a museum is related to lifelong learning and not to a certain curriculum, so that the information transfer promotes the widening of students knowledge through educational approach ${ }^{47}$.

Using the collections as a mean for teaching has another advantage: After getting to know and analysing the objects the students can move around freely and easily. As a result the museum becomes a closer and more familiar place for them, a place of approach rather than rejection ${ }^{48}$.

\section{Conclusions}

A museum is an institution that educates. The cultural heritage defines the museum as an essential component of education. Especially for students and future graduates of human sciences, this parameter is essential ${ }^{49}$.

45. Museumspadagogik, Idealistik, http://bit.ly/1NixXXq.

46. Christine Bäumler, Bildung und Unterhaltung im Museum. Das museale Selbstbild im Wandel [Education and Entertainment ](Münster: LIT, 2014) 22-27, Museums are considered to be places of dealing with the past and with a view to the present and the future.

47. Ellinor Haase, "Lebenslanges Lernen als neuer gesellschaftlicher Imperativ und der Beitrag der Museen" ["Lifelong learning as a new social imperative and contribution of museums"], in Museen neu denken. Perspektiven der Kulturvermittlung und Zielgruppenarbeit, ed. John Hartmut et al., (Bielefeld: transcript-Verlag GmbH, 2008), 88-92; Thorsten Heese, "Außerschulische Lernorte im Geschichtsunterricht: Das Museum" ["Extracurricular places of learning in the teaching of history: The Museum"], in Geschichte erfahren im Museum, ed. Bärbel Kuhn et al. (St. Ingbert: Rohrig Universtitätsverlag, 2014), 13f. According to "contextual model of learning" all learning is situated within series of context, that means learning is not an abstract experience isolated in a laboratory though an experience that happens in real world. The "contextual model" includes three overlapping contexts: the personal, the social, and the physical, John H. Falk et all. "Learning from Museums. Visitor experiences and the making of meaning" (Walnut Creek: Altamira Press, 2000), $10 \mathrm{f}$.

48. Thorsten Heese, "Außerschulische Lernorte im Geschichtsunterricht: Das Museum" ["Extracurricular places of learning in the teaching of history: The Museum"] in Geschichte erfahren im Museum, ed. Bärbel Kuhn et al. (St. Ingbert: Rohrig Universtitätsverlag, 2014), 14.

49. Christine Bäumler, Bildung und Unterhaltung im Museum. Das museale Selbstbild im Wandel [Education and Entertainment] (Münster: LIT, 2014) 27-37. A museum refers also to the humanistic value that the equality of all cultures is a condition of western civilization, see Heiner Treinen. "Das Museumswesen: Fundus für den Zeitgeist" ["Museology: Fundus of the Zeitgeist"] in Das magische Dreieck, ed. Heike Kirchhoff et al., (Bielefeld: transcript-Verlag GmbH, 2007), 35. 
Since the digital world has conquered our lives today, it is important for archaeology to follow this development. In this sense, the online portal of the University of Graz has been founded and includes all University collections. Both of the archaeological collections, the originals and the plaster casts, are part of it. Despite the importance of the web presentation however it cannot replace the visit of a museum itself. Digital world, technology and museums are not inconsistent; they meet different aims and depend on each other.

Only in a University teaching collection like the archaeological collections in Graz didactic and museum educational approaches can flow and complement each other ${ }^{50}$. My personal wish is that the collections will be used further on and more intensively as a living work and research location.

\section{Bibliography}

"Atelier de moulage du Musée du Louvre", Musée du Louvre Corporation. Accessed July 3, 2015. http://bit.ly/1KZdpiS.

Bald-Romano, Irene. "Scholarship in Anthropology, Archaeology, and Ethnography Museums". In Scholarship and museums. Roles and responsibilities, edited by Bryant F. Tolles, Jr. 63. Newark, 1988.

Bauer, Johannes. "Gipsabgußsammlungen an deutschsprachigen Universitäten" ["Plaster Cast Collections at German Universities"]. Jahrbuch für Universitätsgeschichte 5, (2002): 117-132.

Bäumler, Christine. "Bildung und Unterhaltung." [Education and Entertainment]. In Das magische Dreieck, edited by Heike Kirchhoff, Martin Schmidt, 41-56. Bielefeld: transcript-Verlag GmbH, 2007.

Bäumler, Christine. Bildung und Unterhaltung im Museum. Das museale Selbstbild im Wandel. [Education and Entertainment at the Museum. Changing of Museum's self-image]. Münster: LIT, 2014.

Christidis, Maria, Kargl, Carina and Steiner, Elisabeth. "Die archäologischen Sammlungen der Universität Graz auf dem Weg ins digitale Zeitalter" ["Education and Entertainment at the Museum. Changing of Museum's selfimage"]. Forum Archaeologiae 75, VI (2015). Accessed July 7, 2015. http://farch.net.

Christidis, Maria, Karl Stephan, Koiner Gabriele, Schwarz Gerda. "Originalsammlung des Instituts für Archäologie der Karl-Franzens-Universität Graz 1" ["Original Collection of the Institute of Archaeology of the Karl-Franzens-University of

50. "That people learn in museums is easy to state, harder to prove", see John H. Falk et al. Learning from Museums. Visitor experiences and the making of meaning (Walnut Creek: Altamira Press, 2000), 149. Conserning the archaeological collections of Graz, there were not occurred studies about the learning process up to today. Though on a basis of a personally observation of the last lectures kept in the museum, the behavior of the students changed in course of the semester, from a shy behavior at the beginning to the active participation at the end of semester. Additionally, the fact that most of the students completed successfully the lecture points out the importance of the museum as part of the lecture. In the future especially "visitor studies" are intended in order to document the learning process of the students in the didactical collections of Graz. 
Graz 1"]. In Corpus Vasorum Antiquorum, Österreich. Vienna: Verlag der Österreichischen Akademie der Wissenschaften, 2014.

Danguillier, Claudia. "Abgußsammlungen" ["Molding Collections"]. In Gips nicht mehr. Abgüsse als letzte Zeugen antiker Kunst, edited by Johannes Bauer and Wilfried Geominy, 34- 40. Bonn: Köllen Druck und Verlag, 2000.

Desvallées, André. "Definition of Museum". In What is a Museum?, edited by Davis Ann, Mairesse, François and André Desvallées, 121-131. München: Verlag Dr. C. Müller-Straten, 2007.

Douglas, Evelyn E. "Scholarship in the History Museum: New frontiers of doing the job better?." In Scholarship and museums. Roles and responsibilities, edited by Bryant F. Tolles Jr. 41-49. Newark: University of Delaware, Museum Studies Program 1988.

Falk John H., Dierking Lynn D. Learning from Museums. Visitor experiences and the making of meaning. Walnut Creek: Altamira Press, 2000.

Frederiksen, Rune. "Plaster Casts in Antiquity". In Plaster Casts. Making, Collecting and Displaying from Classical Antiquity to the Present, edited by Frederiksen Rune and Marchand Eckart, 15-17. Berlin: De Gruyter, 2010.

Ganev, Uta. Ästhetisch kulturelle Bildung als Handlungsrahmen für Kompetenzerwerb [Aesthetically cultural education as a framework for skills acquisition]. Doctoral Thesis. University of Graz, 2012.

Glock, Andreas. "Museion" ["Museum"]. Der neue Pauly. Enzyklopädie der Antike VIII (2000), 507-511.

Hans-Thuri Lorenz, "Satyroi. Anmerkungen zu einem Brief aus dem Jahre 14883" ["Satyrus. Comments on a letter from the year 14883 "]. In Orham Bingöl's 67. Yas Armagani edited by Görgem Kökdemir, 379-387. Ankara: Bilgin Kultur Sanat.

Haase, Ellinor. "Lebenslanges Lernen als neuer gesellschaftlicher Imperativ und der Beitrag der Museen" ["Lifelong learning as a new social imperative and contribution of museums"]. In Museen neu denken. Perspektiven der Kulturvermittlung und Zielgruppenarbeit, edited by Hartmut John, Anja Dauschek, 88-92. Bielefeld: transcript-Verlag GmbH, 2008.

Heese, Thorsten. "Außerschulische Lernorte im Geschichtsunterricht: Das Museum" ["Extracurricular places of learning in the teaching of history: The Museum"]. In Geschichte erfahren im Museum, edited by Bärbel Kuhn, Susanne Popp, Jutta Schumann and Astrid Windus, 13-21. St. Ingbert: Rohrig Universtitätsverlag, 2014.

Heilmeyer, Wolf D. "Mouseion - Museum: Kleiner Überblick zum Namen und zur Geschichte der Museen" ["Museum: Brief Introduction to the name and the history of museums"]. In Erst erfreuen, dann belehren. Museologie und Archäologie, edited by Wolf D. Heilmeyer, 22-24. Berlin: G+H-Verlag 2013.

Hein, George E. Learning in the Museum. New York: Routledge, 1998.

Heinrich, Markus U. "Zur Herstellung von Gipsabgüssen" ["For the production of plaster casts"]. In Gips nicht mehr. Abgüsse als letzte Zeugen antiker Kunst, edited by Johannes Bauer and Wilfried Geominy, 43- 48. Bonn: Köllen Druck und Verlag, 2000.

Herles, Diethard. Das Museum und die Dinge. Wissenschaft-Präsentation-Pädagogik [The museum and the things. Science-presentation-pedagogy]. Frankfurt: Campus Verlag GmbH, 1996.

Kader, Ingeborg. "Abguß/Abgußsammlung". Der neue Pauly. Enzyklopädie der Antike XIII, (1996), 1-6. 
Karl, S. and Trinkl, E. Studie zur Relevanz archäologischer Reproduktionen für Universitäten, Museen, Denkmalschutz und Forschungsvorhaben [Study on the Relevance of archaeological reproductions of universities, museums, conservation and research projects]. Unpublished final report, Graz, 2014.

"ICOM: The world museum community," Icom Corporation. Accessed May 2015. http://bit.ly/1Bk9R5o.

Landwehr, Christa. Die antiken Gipsabgüsse aus Baiae [The ancient plaster casts of Baiae]. Berlin: Mann Verlag, 1985.

"Lange Nacht der Museen" ["Long Night of Museums "]. ORF Marketing \& Creation GmbH \& Co KG Corporation, accessed June 12, 2015, http://langenacht.orf.at.

Maroevic, Ivo. Introduction to museology. The European approach. Munich: Verlag Dr. Christian Müller-Straten, 1998, 267.

Mairesse, François. "The Term Museum." In What is a Museum?, edited by Ann Davis, François Mairesse and André Desvallées, 19-58. München: Verlag Dr. C. Müller-Straten, 2007.

Mrak, Katharina M. Vermittlung im Museum. Museumspädagogische Konzepte steirischer Museen für Kinder [Mediation in the museum. Educational Concepts of Styrian museums for children]. Master Thesis, University of Graz, 2014.

Pandel, Hans-Jürgen. Geschichtsdidaktik: eine Theorie für die Praxis [Teaching History: a theory for practice]. Schwalbach am Taunus: Wochenschau Verlag, 2013.

Pella: Ergasterio Ekmageion, Ephoria Archaiothton Pellas Corporation. Accessed July 3, 2015. http://bit.ly/1hnspMT.

Pfäffli Brigitta K. Lehren an Hochschulen. Eine Hochsuldidaktik für den Aufbau von Wossen und Kompetenzen [Teaching at universities. Teachning for building competences]. Stuttgarg: Haupt Verlag.

Petrson, Astrid. Wissensvermittlung in Museen. Eine Analyse von Museums- und Ausstellungskonzepten unter Berücksichtigung pädagogischer Lerntheorien am Beispiel des Universalmuseums Joanneum [Knowledge in museums. An analysis of museum and exhibition concepts, taking into account pedagogical theories of learning, using the example of the Universalmuseum Joanneum]. Doctoral Thesis, University of Graz, 2011.

Pochmarski, Erwin. Die Geschichte der archäologischen Sammlungen der Universität Graz [The history of the archaeological collections of the University of Graz], 2008, accessed July, 3, 2015, http://bit.ly/1OXsJRc.

Rese, Bernd. Didaktik im Museum. Systematisierung und Neubestimmung [Teaching at the museum. Systematization and redefinition]. Bonn: Dr. Rudolf Habelt $\mathrm{GmbH}, 1995$.

Romano, Irene B. "Scholarship in Anthropology, Archaeology, and Ethnography Museums". In Scholarship and museums. Roles and responsibilities, edited by Bryant F. Tolles, Jr. 57-63. Newark: University of Delaware, Museum Studies Program, 1988.

Swain, Hedley. An Introduction to Museum Archaeology. New York: Cambringe University Press, 2007.

Talboys, Graeme K. Using museums as an educational resource. An introductory handbook for students and teachers. Brookfield: Arena, 1996.

Treinen, Heiner. "Das Museumswesen: Fundus für den Zeitgeist." ["Museology: Fundus of the Zeitgeist"]. In Das magische Dreieck, edited by Heike Kirchhoff, Martin Schmidt, 27-40. Bielefeld: transcript-Verlag GmbH, 2007.

Uniseum Freiburg, Universität Freiburg Corporation. Accessed July 3, 2015. http://bit.ly/1GtTyUQ. 
Vieregg, Hildegard K. Museumswissenschaften: eine Einführung [Museum Sciences: an introduction]. Stuttgart: UTB Verlag, 2006.

Weschenfelder Klaus, and Zacharias Wolfgang. Handbuch Museumspädagogik. Orientierungen und Methoden für die Praxis [Handbook Museum Education. Orientations and methods for practice]. Düsseldorf: Schwann Verlag KG, 1981. 
